\title{
Kemandirian Berbasis Wakaf di Masjid Besar Imam Ulomo Sampung Ponorogo
}

\author{
Miftahul Huda \\ (Fakultas Syariah Institut Agama Islam Negeri Ponorogo, Jl. Pramuka 156 \\ Ponorogo, Email: elhoeda@yahoo.co.id)
}

\begin{abstract}
Abstrak:
Tulisan ini bertujuan untuk menggali model kemandirian masjid berbasis wakaf di Masjid Besar Imam Ulomo Sampung Ponorogo. Kemandirian masjid dipahami oleh takmir, nâdhir dan jamaah masjid sebagai peningkatan kapasitas masjid dalam berbagai segi. Peningkatan kapasitas masjid itu terdiri dari sisi asset dan sarana prasarana dan dari sisi pengelola masjid. Dari sisi asset dimaknai sebagai upaya meminimalisir beban masyarakat atas kebutuhan masjid. Dari sisi pengelola masjid dimaknai sebagai adanya kesadaran berinovasi dan kebebasan dalam berinisasi untuk penguatan kelembagaan nâdhir dan takmir dalam mengembangkan masjid. Pola atau model kemandirian masjid berbasis wakaf yang diterapkan di Masjid Besar Imam Ulomo Sampung Ponorogo adalah kemandirian aset dengan mengembangkan aset-aset wakaf masjid secara produktif baik dalam pertanian, perikanan maupun lainnya. Sedangkan Pola kemandirian dari sisi penguatan kapasitas nâdhir belum maksimal mengingat nâdhir yang dikembangkan adalah masih dalam kluster nâdhir perorangan. Pola kemandirian yang terakhir adalah pola kemandirian dari sisi manfaat hasil wakaf yang diperuntukkan tidak hanya kepentingan masjid tetapi juga kepentingan jamaah masyarakat sekitar yang membutuhkan.
\end{abstract}

\section{Kata Kunci:}

masjid Wakaf, Sustainability, Kemandirian masjid, Transformasi Sosial

\begin{abstract}
:
This paper aims to explore a model of self-reliance based on wakaf mosque in Imam Ulomo Mosque, Sampung Ponorogo. The independence of the mosque is understood by takmir, nâdhir and mosque congregations as capacity building of mosques in various ways. The capacity building of the mosque consists of assets and infrastructure and from the management of the mosque. In terms of
\end{abstract}


assets interpreted as an effort to minimize the burden of the community on the needs of the mosque. In terms of mosque managers interpreted as an awareness of innovation and freedom in the process of strengthening institutionalization nâdhir and takmir in developing the mosque. Pattern or model of self-reliance Mosque-based wakaf applied at Imam Ulomo Grand Mosque Sampung Ponorogo is the independence of assets by developing the assets of wakaf masjid productively in agriculture, fishery or other. While the pattern of independence from the strengthening capacity nâdhir not maximal considering nâdhir developed is still in individual nâdhir cluster. The last pattern of independence is a pattern of independence from the side of the benefits of wakaf that is destined not only the interests of the mosque but also the interest of the surrounding community.

\section{Keywords:}

masjid Wakaf, Sustainability, Kemandirian masjid, Social Transformation

\section{Pendahuluan}

Gagasan tentang fungsi sosial masjid diperlukan dengan menimbang ulang peranan dan dinamika masjid dalam masyarakat Indonesia modern. Dinamika modernitas nyata-nyata mempengaruhi keberadaan masjid secara fundamental sehingga mengakibatkan munculnya problem identitas kultural masjid. Problem ini dapat dianggap sebagai konsekuensi dan implikasi logis ketika berhubungan dengan modernitas yang memiliki keharusan yang mempengaruhi secara khusus fungsi sosial dan budaya yang didasari atas kewajiban keagamaan. Akibatnya, modernitas memberi tantangan secara langsung terhadap asumsi tradisional dari dunia masjid. Modernitas sendiri membawa perubahan-perubahan dalam banyak aspek kehidupan, khususnya institusi agama seperti masjid itu sendiri.

Fungsi masjid pada zaman Nabi terkonsentrasi kepada tiga aspek, yaitu keagamaan, sosial dan politik pemerintahan. Hal ini terlihat selain masjid Nabawi digunakan untuk ibadah shalat juga tempat menginap kaum ahl-shuffah, tempat memberikan nasihat dan pengajaran ajaran Islam serta tempat memutuskan sengketa dan 
termasuk juga wahana musyawarah mengatur siasat perang dan negara. ${ }^{1}$

Dalam merespons modernitas, masjid mulai mengembangkan usaha produktif guna membiayai kelangsungan roda dan program kehidupan masjid perlu diacungi jempol. Kemampuan Imam masjid dan masyarakat sekitar, menjadi kunci utama untuk meneguhkan atau setidaknya meningkatkan kompetensi masjid dalam visinya itu. ${ }^{2}$ Tetapi, kenyataannya banyak masjid yang merasa kesulitan pendanaan dan mulai berpikir ulang dalam rangka meningkatkan kemampuan finansialnya, dan acapkali menjadi masalah serius sehingga membuat masjid kurang dapat melaksanakan visi dan program utamanya. Apalagi biasanya masjid bergantung pada sumber dana tertentu, seperti pendapatan dari infak sedekah jamaah yang terbatas.

Dari berbagai fakta di atas, perlu upaya lebih serius untuk mendorong berkembangnya program mobilisasi sumber daya untuk mendukung program dan aktivitas yang dilakukan oleh masjid. Salah satu upaya yang urgen dilakukan adalah mendokumentasikan pengalaman dari sebuah masjid yang relatif mampu dalam memobilisasi sumber daya dari sumber wakaf. masjid tersebut adalah Masjid Besar Imam Ulomo Sampung Ponorogo. Pengalaman tersebut bisa digunakan sebagai media untuk meyakinkan masjid untuk lebih meningkatkan kemampuan dalam mengelola wakaf. Hal ini, secara tidak langsung akan semakin menggencarkan dan meningkatkan eksistensi masjid sebagai sub kultur yang tidak bisa dipisahkan dari masyarakat. Karena itu, penting untuk mengkaji tentang bagaimana ikhtiyar masjid menjaga semangat kemandiriannya ketika berhadapan dengan pengaruh kehidupan modern dan mengukuhkan keberlanjutan misinya serta dapat memainkan peran masyarakat madani dalam konteks Indonesia modern melalui institusi wakaf.

Di sisi yang berbeda, perkembangan institusi wakaf saat ini tidak bisa dilepaskan dengan keberadaan Islam di Nusantara. Wakaf, khususnya berupa wakaf tanah, sudah ada dan dilakukan semenjak

1 Harun Nasution, Islam Rasional Gagasan dan Pemikiran Cet. IV, (Bandung: Mizan, 1996), 250-252.

2 Nurodin Usman, "Pengelolaan Wakaf Produktif untuk Kesehatan (Studi Kasus Bandha Wakaf masjid Agung Semarang", Muaddib, Vol. 04, No. 02, Juli Desember 2014. 
lahirnya komunitas-komunitas muslim di beberapa daerah di Nusantara. Lembaga wakaf muncul bersamaan dengan lahirnya masyarakat muslim sebagai sebuah komunitas keagamaan yang pada umumnya memerlukan fasilitas-fasilitas peribadatan dan pendidikan untuk menjamin kelangsungannya. Fasilitas-fasilitas itu dapat terpenuhi dengan cara berwakaf, baik berupa wakaf tanah, bangunan, maupun aset wakaf lainnya. ${ }^{3}$

Pijper melukiskan tentang praktik wakaf di Indonesia terhadap fenomena masjid sebagai sebuah harta wakaf. Harta wakaf tersebut tidak boleh diperjualbelikan, digadaikan, diwariskan, dan dihadiahkan. Hal ini disebabkan masjid itu mempunyai sifat wakaf yang abadi dan langgeng. Artinya, masjid itu selama-lamanya harus digunakan untuk beribadah umat Islam. Sebuah masjid tidak boleh dipindahkan. Jika ada sebuah tempat yang memiliki masjid kemudian ditinggalkan oleh penduduknya sehingga masjid itu tidak digunakan lagi untuk beribadah, maka dilarang juga untuk dibongkar. ${ }^{4}$

Gambaran wakaf di atas tentu membutuhkan perhatian dan penanganan serius. Padahal, secara kuantitatif, potensi wakaf sangat tinggi. Hal ini berdasar data yang dihimpun Kementerian Agama RI melalui Direktorat Pemberdayaan Wakaf tahun 2015. Jumlah tanah wakaf di Indonesia mencapai 4.142.464.287,906 meter persegi atau 414.246 hektare lebih yang tersebar di 435.395 lokasi di seluruh Indonesia. Jumlah tanah wakaf di Indonesia yang begitu besar juga dibarengi dengan sumber daya manusia (human capital) yang sangat besar pula, mengingat Indonesia merupakan negara yang memiliki jumlah penduduk mayoritas muslim. ${ }^{5}$ Belum lagi adanya potensi wakaf bersumber dari donasi masyarakat yang disebut dengan wakaf uang (cash waqf). Jenis wakaf ini membuka peluang besar bagi penciptaan investasi dalam pengelolaan wakaf, yang hasilnya dapat dimanfaatkan pada bidang keagamaan, pendidikan, dan pelayanan sosial. Wakaf jenis ini lebih bernilai benefit daripada wakaf benda tak

\footnotetext{
${ }^{3}$ Miftahul Huda \& Lukman Santoso, "masjid Wakaf dan Transformasi Sosial Umat", Tapis, Vol. 01, No. 01, July 2017.

4 Abdul Ghofur Anshori, Hukum dan Praktek Perwakafan di Indonesia, (Yogyakarta: Pilar Media, 2005), 5.

${ }^{5}$ Miftahul Huda, Mengalirkan Manfaat Wakaf, (Bekasi: Gramata Publising, 2015), 4.
} 
bergerak, seperti tanah. ${ }^{6}$ Asumsi di atas tampaknya sesuai dengan realitas perkembangan wakaf di Indonesia yang mayoritas masih dalam level wakaf konsumtif yang keperuntukannya juga sebagian besar untuk sasaran sosial keagamaan khususnya pesantren, madrasah atau masjid/musolla. ${ }^{7}$

Dalam konteks historis, Masjid Besar Imam Ulomo Sampung Ponorogo Jawa Timur didirikan pada tahun 1927 oleh Kiai Imam Ulomo yang merupakan Naip pertama di Kecamatan Sampung dan mewakafkan sebagian tanahnya untuk dibangun masjid. Pendirian masjid didasarkan atas keprihatinan Kiai Imam Ulomo melihat daerah Sampung yang tidak memiliki masjid sebagai sarana beribadah umat muslim yang ada. Selain untuk sarana ibadah, masjid tersebut diharapkan adanya kerukunan antar masyarakat. Sepeninggal beliau kepengurusan masjid besar berganti-ganti generasi namun masih juga tidak menambah kepercayaan masyarakat terhadap kepengurusan masjid. ${ }^{8}$

Aset wakaf yang dimiliki Masjid Besar Imam Ulomo terdiri dari tanah wakaf seluas $750 \mathrm{~m}^{2}$ pada tanggal 27 Mei 1987, yang diwakafkan oleh Kiai Imam Ulomo. Sampai akhirnya tahun 2009 Bapak Marsudi mewakafkan tanah pertanian berupa sawah dengan luas $1500 \mathrm{~m}^{2}$ yang saat ini masih produktif, yang hasilnya akan disalurkan untuk donasi anak yatim dan miskin di wilayah Kecamatan Sampung. Potensi jama'ah masjid yang banyak, dengan perkembangan aktivitas peribadatan dalam masjid yang masih aktif. Di luar konteks wakaf, dana infak dan sedekahnya pun lebih menjanjikan. Sedangkan hasil produktivitas sawah dalam setahun sekitar 5 -5,5 juta. ${ }^{9}$

Saat ini potensi Masjid besar Imam Ulomo sangat besar, seperti jama'ah masjid yang banyak, dengan aktivitas peribadatan

${ }^{6}$ Mustafa Edwin Nasution \& Uswatun Hasanah, Wakaf Tunai Inovasi Finansial Islam: Peluang dan Tantangan Dalam Mewujudkan Kesejahteraan Umat, (Jakarta: Pusat Kajian Timur Tengah dan Islam Universitas Indonesia bekerja sama dengan Bank Indonesia, Serta Departemen Agama RI, 2006), 41-43.

7 Direktorat Pengembangan Zakat dan Wakaf. Paradigma Baru Wakaf di Indonesia. (Jakarta: Direktorat Jendreral Bimbingan Masyarakat Islam dan Penyelenggaraan Haji Kemenag, 2015).

8 Abdul Azis, Hasil Wawancara, 16 April 2017.

${ }_{9}^{9}$ Nur Hasyim, Hasil Wawancara, 16 April 2017. 
dalam masjid yang masih aktif. Aset wakaf terus berkembang, dana infak dan sedekah lebih menjanjikan. Hasil produktivitas sawah wakaf juga mulai berkembang. Masjid Besar Imam Ulomo merupakan masjid di kecamatan Sampung yang memiliki fungsi sebagai pusat dakwah, pusat kegiatan keagamaan dan tempat pembinaan jama'ah. Di samping realitas di atas, terbentuknya susunan nadhîr yang baru mulai menumbukan kesadaran wakaf pada masyarakat sehingga banyak wakif-wakif baru untuk mencapai tujuan kemakmuran Masjid Besar Imam Ulomo. Nadhîr baru ini menahkodai pengelolaan aset wakaf berbasis masjid dengan lebih profesional dibanding sebelumnya.

Asumsi di atas tampaknya sesuai dengan realitas perkembangan wakaf di Indonesia yang mayoritas masih dalam level wakaf konsumtif yang keperuntukannya juga sebagain besar untuk sasaran sosial keagamaan khususnya masjid/musolla/langgar. ${ }^{10}$ Walaupun demikian ada upaya dan ikhtiyar lebih untuk mewujudkan dan melakukan kemandirian masjid berbasisi wakaf yang tadinya hanya berdimensi sosial keagamaan menuju dimensi sosial ekonomi. Hal ini mulai terjadi di beberapa pemberdayaan aset wakaf berbasis masjid di beberapa daerah termasuk di Masjid Besar Imam Ulomo Sampung Ponorogo Jawa Timur. Mewujudkan usaha Masjid Besar Imam Ulomo sebagai pusat sosial masyarakat berbasis wakaf membutuhkan ihktiyar upaya yang serius. Berpijak pada pemikiran di atas, tulisan ini melakukan identifikasi atas pola atau model masjid wakaf dan kemandiriannya di Masjid Besar Imam Ulomo Sampung Ponorogo.

\section{Wakaf dan Kemandirian masjid}

Wakaf memiliki akar teologis yang kuat. Al Qur'an, meskipun tidak menyebutkan secara eksplisit istilah wakaf, jelas mengajarkan urgensitas kedermawanan sosial untuk berbagai tujuan yang baik. ${ }^{11}$ Hadis Nabi dan praktik Sahabat menunjukkan bahwa wakaf sesungguhnya bagian dari inti ajaran Islam. Namun dalam

10 Direktorat Bimas Islam, Kementerian Agama, 2015.

11 Dalam Al-Qur'an, "wakaf" dimaknai sebagai suatu perbuatan berderma sejatinya merupakan bagian dari esensi philantropi seperti konsep khayr (Q.S al-Hajj 22: 77), konsep infâq (Q.S al-Baqarah 2: 267) dan birr (Q.S Ali 'Imran 3: 97). 
perkembangannya, institusi wakaf tidak bisa dilepaskan dari dinamika sosial, ekonomi, budaya yang mengiringi perkembangan masyarakat Islam dari masa ke masa. Wakaf dalam bentuk yang sederhana telah dipraktikkan para sahabat atas petunjuk Nabi. Salah satu riwayat yang menjadi dasar praktik wakaf pada masa awal Islam adalah hadis Ibn Umar. Hadis ini mengisahkan 'Umar Ibn Khattab yang mendapatkan sebidang lahan di daerah subur Khaibar dekat Makkah. 'Umar yang hendak bersedekah dengan lahan ini menanyakan kepada Nabi perihal niatnya tersebut, dan Nabi bersabda, "Jika engkau bersedia tahan asalnya dan sedekahkan hasilnya". ${ }^{12}$

Ungkapan Nabi di atas pada gilirannya menjadi landasan normatif dan doktrinal wakaf. Hadis itulah kemudian menjadi inti atau substansi definisi wakaf yaitu menahan asal dan mengalirkan hasilnya. Adapun pemilihan makna ini, Al Kabisi mengungkapkan argumentasinya: pertama, makna wakaf di atas langsung dikutip dari hadis Nabi kepada 'Umar. Nabi adalah orang yang paling benar ucapannya dan yang paling sempurna penjelasannya dan yang paling mengerti akan sabdanya. Kedua, pemaknaan ini tidak ditentang oleh pendapat berbagai mazhab fiqh. Dan ketiga, makna ini hanya membatasi pada hakikat wakaf saja dan tidak mengandung perincian

12 Diriwayatkan dengan berbagai redaksi yang hampir sama oleh Bukhârî (1987:II/840), Muslim (III: 1255-1256), Tirmidzî (II: 417), Abû Dâwûd (III: 116-117), Ibnu Majah (II: 801) dan Nasa'i (1420 H:VI/230-232), lebih lengkapnya lihat Ibrahim Mahmud 'Abd al-Baqî, Dawr al Waqf fi Tanmiyat al Mujtamâ' al Madanî: Namudaj al Amânah al 'Ammah li al Awqaf bi Dawlah al Kuwayt, (Daulah Kuwayt: Al Amanah al 'Ammah li al Awqaf Idarah ad-Dirasah wa al 'Alaqat al-Kharijiyyah, 2006), 16. Adapun redaksinya adalah:

$$
\begin{aligned}
& \text { حدثنا قتيبة بن سعيد حدثنا محمد بن عبد الله الأنصاري حدثنا ابن عون قال أنبأني نافع عن ابن عمر رضي الله عنهما }
\end{aligned}
$$

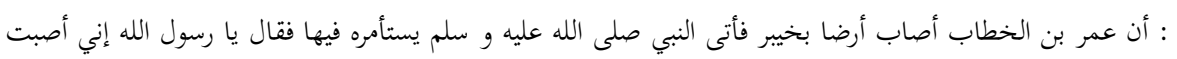

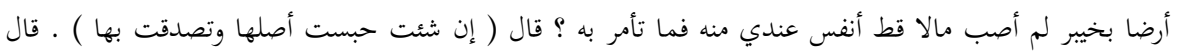

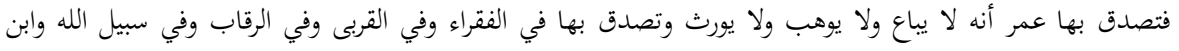

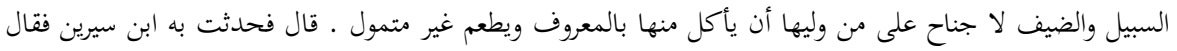

$$
\begin{aligned}
& \text { غير متأثل مالا }
\end{aligned}
$$


yang dapat mencakup definisi lain, seperti niat taqarrub kepada Allah, status kepemilikan, konteks waktu dan sebagainya. ${ }^{13}$

Landasan hadis ini melahirkan minimal lima prinsip umum yang membentuk kerangka konsepsual dan praktik wakaf. Pertama, bahwa kedudukan wakaf sebagai sedekah sunnah yang berbeda dengan zakat. Kedua, kelanggengan aset wakaf, sehingga harta wakaf tidak boleh diperjualbelikan, diwariskan maupun disumbangkan. Ketiga, keniscayaan aset wakaf untuk dikelola secara produktif. Keempat, keharuskan menyedekahkan hasil wakaf untuk berbagai tujuan yang baik. Kelima, diperbolehkannya nâdhir wakaf mendapatkan bagian yang wajar dari hasil wakaf. ${ }^{14}$

Dalam konteks inilah, sangat penting apabila mengaitkan aktivitas pengelolaan dan pengembangan wakaf dengan institusi masjid. Peran nâdhir wakaf masjid saat ini sungguh dibutuhkan mobilisasi kerjanya. Dengan ini, diharapkan institusi wakaf mempunyai signifikansi dalam meneguhkan kemandirian dan ihtiyar pencapaian visi masjid. Artinya dukungan finansial maupun non finansial akan sangat berguna bagi kelangsungan masjid. Agar masjid tetap sustainability dan berkemandirian, maka masjid membutuhkan sumber-sumber daya/dana dalam menopang tujuan luhurnya.

masjid wakaf, yaitu masjid yang dibangun dengan kedermawanan atau philantropi Islam berupa institusi wakaf dipandang cukup tepat sebagai model pengembangan kemandirian masjid di era Indonesia kontemporer. Proses pengembangan masjid wakaf dapat dilakukan dengan beberapa pilar kekuatan pendorong: 1) Kelembagaan masjid wakaf dilakukan secara profesional dalam bentuk perseorangan, organisasi atau badan hukum/yayasan, 2) Pengelolaan aset-aset wakaf secara produktif, dan 3) Penyaluran hasil wakaf baik untuk internal masjid maupun masyarakat, serta 4) pelaporan hasil wakaf masjid yang transparan dan akuntabel. ${ }^{15}$

Ada banyak model dan gambaran tentang masjid sehingga perlu untuk melakukan kategorisasi dalam suatu definisi lebih flexibel dan mungkin lebih baik mengambil aspek esensi atau

${ }_{13}$ Muhammad Abid Abdullah Al-Kabisi, Hukum Wakaf, (Jakarta: IIMaN Press, 2004), 61-62.

14 Tuti A Nadjib \& Ridwal Al-Makassary., Wakaf, Tuhan, dan Agenda Kemanusiaan, (Jakarta: CSRS UIN Jakarta, 2006), 30.

${ }^{15}$ Miftahul Huda, Mengalirkan Manfaat Wakaf (Jakarta: Gramata Publishing, 2015), 352. 
substansi dari masjid. Dari sisi ini, dapat digambarkan model komprehensif tentang masjid: pertama, mengembalikan fungsi masjid sebagaimana zaman awal Islam dengan harapan kejayaan Islam dapat tercapai. Kedua, membiarkan masjid seperti yang ada saat ini, tetapi dengan memperkuat peran dan fungsi masjid yang sudah ada secara maksimal dalam bentuk dikotomis dan terpisah. Ketiga, mengakomodir dengan paling tidak menghidupkan kemabli aspek ibadah dan juga memperhatikan fungsi sosial ekonominya. ${ }^{16}$

Dalam rangka meneguhkan kemandirian dan ihtiyar pencapaian visi masjid, maka dibutuhkan instrumen khusus untuk meneguhkan kemandirian masjid dan program kerjanya. Artinya dukungan finansial maupun non finansial akan sangat berguna bagi kelangsungan masjid. Instrumen itu adalah institusi wakaf, yang memang secara tradisi intelektualitas muslim klasik sengat erat dan berkelit kelindang dengan lembaga sosial pendidikan muslim. Karena itu, usaha mengungkap gambaran mengenai strategi nâdhir berbasis masjid dalam menggalang sumber daya/dana wakaf untuk kemandirian masjid.

Problem keuangan dirasakan oleh banyak masjid. Hal ini membuat masjid tidak hanya sulit mengembankan kegiatan, untuk pembangunan sarana masjid terpaksa harus meminta dari pinggir jalan, di perempatan lampu merah, dan lain-lain. Minimnya dana masjid karena umumnya masjid hanya mengandalkan pendapatannya dari infak jumat. Karenanya perlu dilakukan usahausaha lain yang halal dan tidak mengikat seperti menangani jasa pembayaran rekening listrik, telepon dan lainnya. ${ }^{17}$

Pengelolaan dan pemakmuran masjid secara baik tentu saja memerlukan dana yang tidak sedikit. Bila masjid hanya mengandalkan dana dan tromol jumat, maka hal itu tidak mencukupi, sementara biaya operasional masjid, baik perawatan bangunan honor pelaksana maupun aktivitasnya cukuplah besar. Karena itu pengurus masjid perlu mengupayakan usaha-usaha guna menopang biaya yang dibutuhkan masjid. Usaha yang dapat dilakukan anatar lain:, pertama

16 M Fajrul Munawir, "Fungsi Majid Antara Realita dan Idealita" dalam Fakultas dakwah UIN Yogyakarta, Model-model Kesejahteraan Sosial Islam, (Yogyakarta, PMIDakwah UIN Sunan Kalijaga-IISEP CIDA, 2007), 141-142.

17 Ahmad Yani dan Achmad Satori Ismail, Menuju masjid Ideal, (Jakrat: LP2SI Al Haramain, 2001), 92. 
mengupayakan adanya donatur tetap yang diambil setap bulannya. Kedua menghimpun dan mengelola dana inak sedekah dan zakat, ketiga, BMT yang menggunakan sistem syariah guna menghimpun dana umat dan mengembnagkannya untuk kepentingan umat. Keempat, penyewaaan ruang aula untuk berbagai kegiatan. Kelima, membuka mini market atau koperasi masjid yang menjual berbagai keperluan rumah tangga. Keenam, penyewaan investaris masjid seperti sound system, kursi, tenda dan sebagainya. ${ }^{18}$

Dalam upaya menjadikan sebuah masjid yang mandiri, adapun beberapa langkah dibawah ini yang mungkin dapat membantu pengurus masjid dalam mengatur aktivitas pemakmuran masjid, antara lain, (1) konsolidasi pengurus, (2) konsolidasi jamaah, (3) perumusan program kerja, (4) memperbaiki mekanisme kerja, (5) menumbuhkan sense of belonging terhadap masjid, (6) melengkapi fasilitas masjid, (7) menggalang pendanaan masjid. ${ }^{19}$

Banyak ilmuan yang membedakan bentuk dari kemandirian, salah satunya Robert Havighutst. Beliau menyebutkan ada 3 bentuk kemandirian yakni :

a. Kemandirian emosi, yaitu kemampuan mengontrol emosi sendiri dan tidak tergantungnya kebutuhan emosi pada orang lain

b. Kemandirian ekonomi, yaitu kemampuan mengatur ekonomi sendiri dan tidak tergantungnya kebutuhan ekonomi pada orang lain.

c. Kemandirian intelektual, yaitu kemampuan untuk mengatasi berbagai masalah yang dihadapi. ${ }^{20}$

Peneliti sendiri, sering menemukan realitas kemandirian melekat bukan hanya pada sisi seseorang melainkan sebuah lembaga baik pendidikan, social dan lembaga dakwah sendiri. masjid merupakan sebagai salah satu lembaga dakwah yang diharapkan mampu memiliki kemandirian. Spesifiknya dalam penelitian ini adalah kemandirian pada aspek ekonomi. Sehingga bisa didefisinikan makna kemandirian masjid adalah keadaan sebuah masjid mampu

\footnotetext{
18 Ibid., 25-27.

19 Ibid., 93-97.

${ }^{20}$ Ibid., 37
} 
membiayai segala kebutuhan dalam menjalankan fungsinya dengan memanfaatkan segala sumber daya yang dimilikinya.

Maka, ciri-ciri dikatakan masjid yang memiliki kemandirian dalam ekonomi meliputi :

a. Pengurus di dalam masjid tersebut senatiasa memiliki berbagai inovasi dan inisiatif sendiri untuk menemukan berbagai macam strategi yang bahkan belum pernah terfikirkan oleh lembaga lain dalam upaya mengembangkan masjid baik diaspek kegiatannya, infrastruktur, dan tujuannya dengan mengoptimalkan segala sumberdaya yang dimiliki secara mandiri tanpa mengandalkan pihak lain.

b. Pengurus masjid mampu mengambil keputusan dalam menetapkan strategi atau memecahkan masalah baik yang bersumber dari internal maupun eksternal. Ataupun yang sifatnya mendukung usaha pengembangan masjid ataukah tidak dengan mengoptimalkan segala sumber daya yang dimiliki secara mandiri tanpa mengandalkan pihak lain

c. Pengurus masjid mengoptimalkan segala sumber daya yang dimiliki baik dari sisi sdm, dana, bangunan, dan sebagainya dalam mendukung usaha pengembangan masjid - Pengurus masjid secara sadar, berani dan siap dalam menghadapi segala resiko dalam mengembangkan masjid dengan sumber daya yang dimiliki

d. Pengurus masjid tentu memahami apa yang menjadi visi dan misi dalam pengembangan masjid dan apa yang harus dilakukan sebagai pengembangan visi dan misi tersebut. Sehingga muncul rasa tanggung jawab untuk menjalankan visi dan misi tersebut sendiri.

\section{Pemahaman Masyarakat tentang Kemandirin Masjid}

Masjid sebagai refleksi dari kebutuhan masyarakat muslim atas lembaga keagamaan yang dapat menjadi wahana beramal dan beribadah sholeh seperti sholat lima waktu melakukan majelis taklim dan pengajian-pengajian bersama. Pembiasaan kehidupan berpolakan ajaran Islam, hampir semuanya terbangun pada dasarnya atas dasar swadaya masyarakat sekitar. Sebagaimana diungkap dalam kegiatan di masjid, ada kiai yang memimpin jamaah dan terkadang mengajari keilmuan tertentu kepada masyarakat. Budaya swadaya ini begitu 
kental dalam dunia masjid, dan menjadi pilar kemandirian masjid maupun kemandirian masyarakat. Walaupun demikian bukan berarti masalah pendanaan tidak menjadi problem, tapi tetap menjadi salah satu problema masjid ketika kebutuhan akan sarana semakin meningkat sejalan dengan meningkatnya fungsi-fungsi masjid.

Masalah pendanaan hampir menjadi kendala setiap kepentingan apapun, bagi masjid masalah ini menjadi permasalahan serius ketika dituntut fasilitas sejalan dengan meningkatnya fungi masjid. Sebuah masjid juga harus mempersiapkan sarana dan prasarana agar nyaman bagi orang yang berjamaah. Permasalahan akan semakin komplek ketika masjid membutuhkan sarana prasarana tetapi untuk memenuhi itu, masjid tidak mempunyai kemampuan. Sehingga cara yang paling krusial adalah meminta kepada masyarakat yang hal ini sebagian memberatkan dan menjadi beban tersendiri kepada msyarakat. ${ }^{21}$

Untuk memenuhi kebutuhan pendanaan ini, sejak awal masjid sebagai lembaga swadaya dari masyarakat yang mandiri berusaha menyelesaikannya sendiri, biasanya masjid tidak menggantungkan diri pada bantuan pemerintah baik pusat maupun daerah. Pola-pola swadaya masjid dalam pembangunan biasanya menghidupkan kegiatan infaq dan shadaqah dari kalangan masyarakat dan bahkan dari pengelola masjid sendiri. Dewasa ini jika diinventarisir sumber dana masjid adalah: 1) wakaf, 2) masyarakat muslim, 3) dan intansi pemerintah maupun swasta. ${ }^{22}$

Pertama masyarakat atau jamaah masjid berperan sebagai pelopor pendanaan masjid, baik dari usahanya atau dari hasil pekerjaanya. Tidak jarang para dermawan yang kaya misalkan mengambil jatah pasir, besi atau bahan-bahan material bangunan lainnya, ada juga yang bersedekah kebutuhan bangunan untuk masjid. Selain pola di atas bagi masjid, biasanya pola pengumpulan dana pembangunan dengan mengirimkan delegasi pengumpul dana yang berkeliling ke desa-desa dengan membawa rencanan pembangunan, serta formulir atau list berisikan daftar penyumbang

21 Ahmad Furqon, "Pengelolaan Wakaf Tanah Produktif (Studi Kasus Nazhir Badan Kesejahteraan masjid (BKM) Kota Semarang dan Yayasan Muslimin Kota Pekalongan)", Al-Ahkam, Vol. 26, No. 1, 2016.

22 Miftahul Huda, "Wakaf dan Kemandirian Pesantren dari Gontor Hingga Tebuireng", ISLAMICA, Vol. 07, No. 01, September 2012. 
dengan nominal sumbangan yang diberikan, penerbitan kalender atau penjualan produk masjid. Akhir-akhir ini ada trend baru penghimpunan dana dengan membuat "jaringan" di jalan raya. Selain cara di atas, penghimpunan dana juga dengan jalan silaturahmi kepada para hartawan/pengusaha lokal, biasanya dilakukan sendiri pengelola atau takmir masjid yang berpengaruh dan memaparkan kebutuhannya. Keempat intansi pemerintah maupun swasta serta organisasi-organisasi keagamaan seperti dakwah masjid yang programnya memang mendukung aktivitas dakwah Islamiyah. Untuk intansi yang formal seperti ini biasanya pihak masjid mengajukan permohonan tertulis dengan proposal lengkap.

Adapun wakaf menjadi hal penting kalau seandainya aset wakaf bisa kelola dengan produktif, bukan tidak mungkin wakaf menjadi alternatif pendanaan masjid. Hal ini nampaknya sesuai dengan fungsi dan tujuan kalau masjid itu berbasis wakaf dan dilakukan secara produktif. Dari hasil pengamatan dan wawancara nampak bahwa aset wakaf yang di Masjid Besar Imam Ulomo Sampung sudah dapat melakukan produktivitas aset wakaf baik dalam bentuk pertanian, maupun perikanan. Hasil dari produktivitas ini dapat diginakan untuk pengembangan keagamaan masjid baik dari sisi sarana prasarana maupun kemanfaatan jamaah.

Adapun sisi pengelolaan wakaf yang ada di Masjid Besar Imam Ulomo Sampung yang saat ini telah diterapkan adalah dari sisi penghimpunan aset wakaf oleh nâdhir Masjid Besar Imam Ulomo sudah mulai berkembang. Berawal dari nâdhir bersifat pasif menunggu aset wakaf yang ingin diwakafkan sampai dengan pengajuan proposal terhadap calon wakif yang dipandang mampu, atau melakukan penawaran kepada jamaah masjid ketika pengajian, khutbah jum'at, atau dalam kegiatan amal masjid. Setiap bentuk penghimpunan aset wakaf di buktikan dari penerimaan aset wakaf, antara lain:

a. Aset wakaf berupa tanah yang diserahkan oleh Kiai Imam Ulomo sebagai wakif dengan kerelaaan hati.

b. Aset wakaf pembangunan sumur untuk sarana bersuci jamaah yang dibuktikan oleh kesadaran bewakaf dari pihak wakif. 
c. Aset wakaf berupa sawah yang diserahkan oleh pewakif tanpa paksaan dan diserahkan atas dasar amal jariyah. ${ }^{23}$

Bahkan untuk pagar masjid yang di dapatkan dari pengajuan proposal kepada pihak wakif. Dalam kenyataannya, nâdhir dalam melakukan pengumpulan aset wakaf tidak sepenuhnya dikatakan pasif. Nâdhir selain menunggu wakif baru menyerahkan aset wakafnya juga dengan melakukan pengumpulan dengan media pengajuan proposal (jemput bola), dakwah, khutbah jum'at dan acara-acara yang sifatnya insidentil. ${ }^{24}$

Pengelolaan harta wakaf misalnya untuk masjid dilakukan oleh ta'mir masjid diluar fungsi utama masjid sebagai sarana peribadatan namun di dukung dengan berbagai kegiatan masjid yang lebih maksimal misalnya kegiatan remaja masjid. Pengelolaan aset wakaf yang berupa sumur memang sepenuhnya untuk persediaan air masjid namun tidak jarang disalurkan ke beberapa rumah penduduk sekitar masjid tanpa penetapan tarif. Berdasarkan kerelaan dan rasa toleransi terkadang warga juga memberikan uang dengan dalih untuk mengganti uang listrik. Sedangkan untuk sawah pengerjaannya bekerja sama dengan masyarakat sebagai pengarap, namun sejauh ini salah satu ta'mir bersedia menggarapnya. Dalam hal ini hasil panen yang sudah di potong bagian penggarap di jual dalam wujud gabah kering, lalu di bagikan ke anak yatim dan manula di wilayah sampung menunggu tiap bulan Suro. Begitu juga pengembangan aset wakaf dalam bentuk perikanan kolam ikan lele, nujair dan Nila. Pengembangan kolam ikan ini menghasilkan keuntungan yang relatif besar karena setiap 3 bulanan panen Ikan tersebut dan secara penjualan mudah dengan harga yang kompetitif. ${ }^{25}$

Penyaluran aset wakaf dilakukan oleh nâdhir bekerja sama dengan ta'mir masjid besar Imam Ulomo. Dalam penyalurannya di bagi dalam dua jenis bidang yang saling terkait, mulai dari agama (ritual keagamaan/ ibadah) dan juga untuk sosial. Penyaluran dalam hal agama atau ibadah diwujudkan dalam bangunan masjid selain sebagai sarana ibadah, tempat pembinaan jama'ah dan juga sebagai

\footnotetext{
${ }^{23}$ Nur Hasyim, Hasil Wawancara, 22 Agustus 2017.

24 Ibid.

25 Joko Waluyo, Hasil Wawancara, 22 Agustus 2017.
} 
pusat dakwah masyarakat. Sebagaimana tujuan wakif, sumurpun diwakafkan untuk kepentingan masjid dalam rangka penyediaan air bersih untuk jama'ah namun dalam kenyataannya juga membantu warga sekitar masjid yang terkadang masih kesulitan mendapatkan air. Penyaluran aset wakaf dari hasil panen sawah bersifat konsumtif saja sejauh ini. Penyaluran diberikan dalam bentuk santunan kepada anak yatim dan manula disekitar wilayah Sampung. Penerima hasil wakaf biasanya dilihat berdasarkan pemetaan atau mengandalkan informasi dari pihak lain yang dapat dipercaya dan amanah. ${ }^{26}$

Pelaporan yang transparan dan akuntansi sederhana sudah dilakukan nâdhir khususnya dalam kepengurusan ta'mir masjid Imam Ulomo sebagai tanggung jawabnya memberikan informasi yang terbuka kepada masyarakat. Penyampaiannyapun dilakukan ketika dilakukan pertemuan rutin karena menyadari dalam mewujudkan kesejahteraan masjid merupakan tugas semua pihak. Dimana pelaporan sangat menentukan beberapa hal antara lain: kewajiban nâdhir menyediakan media laporan wakaf untuk di audit independent dan menjaga kepercayaan untuk semua pihak termasuk masyarakat dan bentuk tanggung jawab nâdhir kepada wakif. ${ }^{27}$

\section{Pola Kemandirian Sisi Kelembagaan}

masjid Besar Imam Ulomo Sampung Ponorogo Jawa Timur didirikan pada tahun 1927 oleh Kiai Imam Ulomo yang merupakan naip pertama di Kecamatan Sampung dan mewakafkan sebagian tanahnya untuk dibangun masjid. Pendirian masjid didasarkan atas keprihatinan Kiai Imam Ulomo melihat daerah Sampung yang tidak memiliki masjid sebagai sarana beribadah umat muslim yang ada. Selain untuk sarana ibadah, masjid tersebut diharapkan adanya kerukunan antar masyarakat. Sepeninggalnya, kepengurusan masjid besar berganti-ganti generasi namun masih juga tidak menambah kepercayaan masyarakat terhadap kepengurusan masjid.

Saat ini potensi masjid besar Imam Ulomo sangat prospektif, seperti jama'ah masjid yang banyak, dengan aktivitas peribadatan dalam masjid yang masih aktif. Aset wakaf terus berkembang, dana infak dan sedekah lebih menjanjikan. Hasil produktivitas sawah

\footnotetext{
26 Abdul Azis, Hasil Wawancara, 22 Agustus 2017.

27 Ibid.
} 
wakaf juga mulai berkembang. masjid Besar Imam Ulomo merupakan masjid di kecamatan Sampung yang memiliki fungsi sebagai pusat dakwah, pusat kegiatan keagamaan dan tempat pembinaan jama'ah.28Di samping itu, terbentuknya susunan nâdhir yang baru mulai menumbukan kesadaran wakaf pada masyarakat sehingga banyak wakif-wakif baru untuk mencapai tujuan kemakmuran masjid besar Imam Ulomo. Nâdhir baru ini menahkodari pengelolaan aset wakaf berbasis masjid dengan lebih profesional di banding sebelumnya. ${ }^{29}$

Selain untuk sarana ibadah, dengan didirikan masjid tersebut diharapkan ada kerukunan antar masyarakat yang kepengurusannya masih dilakukan oleh Kiai Imam Ulomo. Sepeninggalan beliau kepengurusan masjid besar berganti-ganti generasi namun masih juga tidak menambah kepercayaan masyarakat terhadap kepengurusan masjid. Setelah sekian lama kepengurusan masjid besar Imam Ulomo terbengkalai kemudian pada tahun 2009 dibentuklah kepengurusan baru yang dilakukan secara musyawarah dengan masyarakat, ulamaulama serta pengurus masjid atau mushola yang berada di sekitar desa Sampung maka terbentuklah susunan nâdhir baru yang didukung dan didorong dari semua lapisan masyarakat.

Dengan adanya susunan nâdhir nâdhir yang baru mulai menumbukan kesadaran wakaf pada masyarakat sehingga banyak wakif-wakif baru untuk mencapai tujuan kemakmuran masjid besar Imam Ulomo. Pada tahun 2005 seorang wakif yang bernama Nur Hasyim berwakaf untuk pembuatan sumur alami sebagai sarana bersuci karena di Desa Sampung masyarakat hanya mengandalkan air dari PDAM yang terkadang tidak mengalir. Selanjutnya ada juga wakaf tanah pertanian berupa sawah pada tahun 2009 sistem penggarapannya ditanami sesuai dengan musimnya. ${ }^{30}$

Kegiatan penguatan administrasi dan kelembagaan nâdhir di awali dengan koordinasi dengan ketua nâdhir sebelumnya. Sosialisasi paradigma tata kelola wakaf produktif difokuskan pada penjelasan dan pemahaman terkait konsep dan aplikasi wakaf produktif serta

28 Observasi pada 7 September 2017.

29 Tim Penulis, Album masjid Besar Imam Ulomo Sampung (Sampung: Takmir masjid, 2011).

30 Abdul Aziz, Hasil Wawancara, 14 Agustus 2017. 
bagaimana tata kelola aset wakaf agar semakin produktif. Sementara sosialisasi penguatan Kelembagaan nâdhir wakaf difokuskan pada penjelasan dan penjabaran fungsi nâdhir dan kelembagaan nâdhir sebagai ujung tombak dalam mewujudkan wakaf produktif. ${ }^{31}$ Beberapa point penting adanya kemandirian dasi sisi kelembagaan, dapat disimpulkan sebagai berikut:

a. Dari memahami esensi wakaf bersifat sosial keagamaan ritual menuju wakaf bersifat sosial ekonomi

b. Dari landasan wakaf dalam kitab fikih saja tapi juga harus menuju landasan wakaf fikih indonesia (peraturan perundangan)

c. Dari memahami wakaf bersifat informal menuju wakaf formal yustisial/administratif

\section{Pola Kemandirian Sisi Aset}

Aset wakaf yang dimiliki Masjid Besar Imam Ulomo terdiri dari tanah wakaf seluas $750 \mathrm{~m}^{2}$ pada tanggal 27 Mei 1987, yang diwakafkan oleh Kiai Imam Ulomo selaku nầib pertama di Kecamatan Sampung. Walaupun dengan keterbatasan baik dengan tenaga maupun materi beberapa jamaah sekitar masjid juga sangat peduli pada saat pembangunan masjid wakaf ini mulai dari memberikan semen, batu bata, dan tenaga secara cuma-cuma. ${ }^{32}$

Berawal dari kesadaran jamaah itulah, akhirnya Nur Hasyim merelakan sedikit hartanya membuat sumur bor alami dengan tujuan untuk persediaan air bersih jamaah. Sampai akhirnya tahun 2009, Marsudi mewakafkan tanah pertanian berupa sawah dengan luas $1500 \mathrm{~m}^{2}$ yang saat ini masih produktif, yang hasilnya akan disalurkan untuk donasi anak yatim dan miskin di wilayah Kecamatan Sampung. ${ }^{33}$

Potensi jamaah masjid yang banyak, dengan segelintir aktivitas peribadatan dalam masjid yang masih aktif. Di luar konteks wakaf, dana infak dan sedekahnya pun lebih menjanjikan. Jika hasil

\footnotetext{
31 Achmad Arief Budiman, “ Partisipasi Stakeholder dalam Perwakafan (Studi Kasus di Rumah Sakit Roemani, Yayasan Badan Wakaf Sultan Agung, dan masjid Agung Semarang)", Al-Ahkam, Vol. 26, No. 1, April 2016.

32 Abdul Azis, Hasil Wawancara, 12 Oktober 2017.

33 Nur Hasyim, Hasil Wawancara, 2 Oktober 2016.
} 
produktivitas sawah dalam setahun sekitar 5,5 juta, maka masjid memiliki kecukupan dana yang lebih.

Tabel. Aset Wakaf masjid

\begin{tabular}{|c|l|c|}
\hline No & Aset Wakaf masjid & Jumlah \\
\hline 1 & Sumur air minum & 1 \\
\hline 2 & Tanah wakaf masjid & $750 \mathrm{~m}^{2}$ \\
\hline 3 & Tanah sawah & $1500 \mathrm{~m}^{2}$ \\
\hline 4 & Kolam Ikan & 2 \\
\hline & Jumlah & $2250 \mathrm{~m}^{2}$ \\
\hline
\end{tabular}

Sesungguhnya wakaf produktif merupakan upaya menciptakan sumber pendanaan/kapital berbasis aset wakaf yang dikelola dengan membangun unit-unit usaha yang mendatangkan surplus (keuntungan), dan menggunakan surplus itu untuk pemberdayaan sosial ekonomi atau layanan sosial keagamaan. Hal ini terbukti dengan ikhtiyar melakukan produktivitas aset wakaf dalam bentuk perikanan yang menempati aset wakaf tananh di samping masjid dan mendapatkan keuntungan yang cukup besar. ${ }^{34}$

Pengelolaan dan pengembangan harta benda wakaf dilakukan secara produktif antara lain dengan cara pengumpulan, investasi, penanaman modal, produksi, kemitraan, perdagangan, agrobisnis, pertambangan, perindustrian, pengembangan teknologi, pembangunan gedung, apartemen, rumah susun, pasar swalayan, pertokoan, perkantoran, sarana pendidikan ataupun sarana kesehatan dan usaha-usaha yang tidak bertentangan dengan syariah. Berikut bagan anasir wakaf produktif:

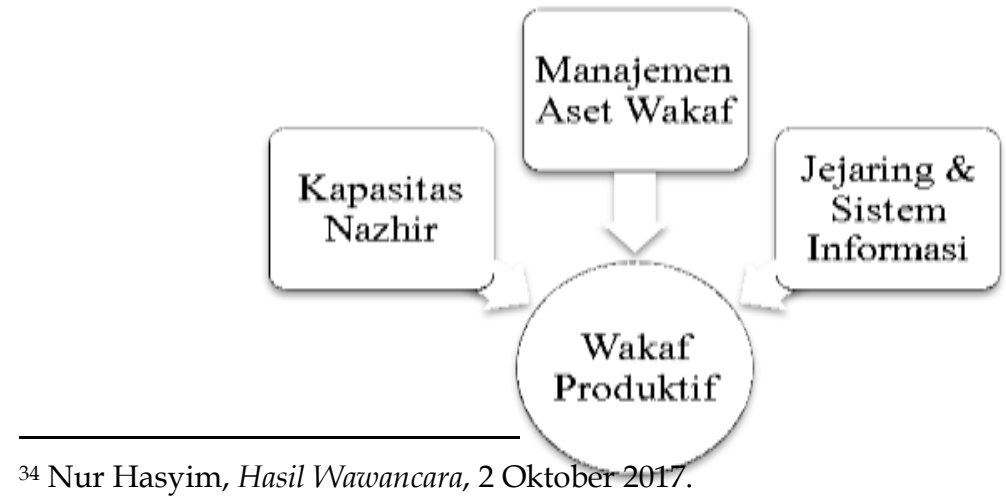


Beberapa gagasan dan diskusi yang muncul dan relevan untuk dikembangkan dalam pengembangan aset wakaf produktif, yaitu:

a) Terkait pemberdayaan jamaah masjid wakaf untuk diberdayakan mengelola sumber daya hutan desa. Bagaimana mengelola tanah hutan desa tersebut agar produktif bersama, akan ditanami apa atau diadakan training apa, serta upaya adanya suntikan dana untuk pengelolaan sumber daya hutan desa tersebut.

b) Upaya memanfaatkan ruang kosong di gudang masjid wakaf sebagai tempat budidaya jamur tiram. Mulai dari pelatihan penyediaan media tanamnya hingga sampai pada penanaman.

c) Upaya pemanfaatan lahan kosong di sekitar masjid wakaf sebagai kolam ikan produktif. Upaya yang perlu disiapkan adalah media kolam, sirkulasi air, pemberian benih ikan dan pemeliharaan secara periodik.

d) Terkait upaya pendampingan terhadap mushola di sekitar masjid wakaf yang memiliki tanah wakaf namun terkendala administrasi karena belum terdaftar di badan wakaf Indonesia. Bagaimana kelembagaannya agar asetnya dapat dikelola dengan maksimal melalui penguatan status kelembagaan nâdhir, sehingga dapat menjadi bagian dari jaringan nâdhir di Kabupaten Ponorogo.

e) Terkait dengan adanya aset wakaf musola di sekitar masjid wakaf yang status sertifikat tanahnya masih ikut bagian pihak yang mewakafkan. Upaya sertifikasi mandiri berhenti di tengah jalan sejak tahun 2014. Sementara ikrar wakaf di KUA belum dilaksanakan dan konfirmasi kejelasan status tanah ke pihak BPN.

Maka, berdasarkan diskusi dan sharing dari para nâdhir, takmir dan jamaah masjid wakaf, berdasarkan skala prioritas diputuskan 2 program yang akan dilaksanakan pendampingan, yaitu: 1) Sosialisasi administrasi dan penguatan kelembagaan nâdhir, 2) 
Training pengelolaan wakaf produktif pengembangan aset pertanian dan perikanan.

Maka, di era modern perlu dibangun mindset paradigma baru pengelolaan wakaf produktif, yaitu:

a. Dari menghimpun sumber wakaf pasif menuju menghimpun sumber wakaf aktif bahkan kreatif.

b. Dari mengelola aset wakaf konsumtif menuju mengelola aset wakaf produktif bahkan benefit.

c. Dari menyalurkan hasil wakaf cuma-cuma/charity menuju menyalurkan hasil wakaf yang memberdayakan bahkan advokatif.

d. Dari melaporkan hasil wakaf yang tertutup menuju melaporkan hasil wakaf terbuka/transparan bahkan akuntabel.

\section{Pola Kemandirian dan Sisi Manfaat}

Untuk kegiatan pengembangan wakaf dan penguatannya dengan melalui kegiatan penguatan paradigma tata kelola wakaf produktif dan penguatan kelembagaan nâdhir wakaf. Hasilnya ada perubahan midset jamaah masjid tentang wakaf produktif semakin baik. Sehingga penguatan ini menghasilkan terwujudnya pemahaman seputar wakaf produktif, tercipta Paradigma tata kelola wakaf produktif pada nâdhir, serta terwujudnya kemitraan dalam pemberdayaan wakaf produktif. Sedangkan terkait pelatihan administrasi wakaf, terjadi peningkatan pemahaman dalam menyelesaikan prosedur administratif wakaf, mulai dari ikrar wakaf di KUA sampai sertifikasi wakaf di BPN.

\begin{tabular}{|l|l|l|}
\hline \multicolumn{2}{|c|}{ HASIL PENGEMBANGAN ASET WAKAF PRODUKTIF } \\
\hline Ikhtiyar & $\begin{array}{l}\text { Hasil } \\
\text { Pengembangan Aset } \\
\text { Wakaf Produktif }\end{array}$ & \\
\hline - Pengembangan & - Terwujudnya & - Terlaksananya \\
aset wakaf dalam & kolam untuk & pengembangan \\
bentuk budidaya & budidaya ikan & aset wakaf \\
ika kolam & - Terwujudnya area & produktif \\
- Holtikultura dalam & masjid wakaf untuk & budidaya ikan dan \\
\hline
\end{tabular}




\begin{tabular}{|c|l|l|}
\hline area wakaf masjid & tanaman & holtikultura yang \\
- Program distribusi & holtikultura & sebelumnya belum \\
hasil wakaf & - Terwujudnya & ada \\
& program santunan & - Terlaksananya \\
& yatim piatu dan & penyaluran hasil \\
duafa dari hasil & wakaf produktif \\
& wakaf & $\begin{array}{l}\text { bagi masyarakat } \\
\text { umum }\end{array}$ \\
\hline
\end{tabular}

Sementara itu, untuk penguatan kelembagaan nâdhir dan peningkatan produktivitas aset wakaf, maka terwujudlah kolam ikan dan insentif budidaya ikan. Adapun impikasi jangka panjang yang diharapkan dari telah terlaksananya kegiatan ini adalah semakin baiknya tata kelola wakaf produktif dan kelembagaan nâdhir sehingga pengembangan aset wakaf secara produktif berdampak pada berkembangnya kemadirian masjid Besar Imam Ulomo Sampung Ponorogo.

Untuk itu, mindset tata kelola wakaf dan kelembagaan nâdhir wakaf masjid besar Imam Ulomo Sampung harus diberdayakan agar masjid sebagai lembaga Sosial Keagamaan juga merambah pada lembaga Sosial Ekonomi. Selain itu, penguatan jaringan dan kemitraan dengan berbagai stakeholders, mulai dari KUA, pemerintah desa, BWI, dan BPN harus terus dibangun semakin sinergis.

\section{Penutup}

Pemahaman Masyarakat termasuk nâdhir dan jamaah masjid Besar Imam Ulomo Sampung tentang kemandirian masjid adalah kemandirian dari kemampuan masjid dalam sisi aset dan pendanaan sehingga masjid tidak harus membebani masyarakat dalam pengembangan masjid sendiri. Masyarakat juga memahami kemandirian masjid dipahami sebagai kemampuan pengurus atau nâdhir yang mempunyai kebebasan, inisiasi dalam mengembangkan pengelolaan masjid. Pengurus beserta partisipasi masyarakat mempunyai kesadaran penuh dalam melakukan transformasi ke arah yang lebih baik untuk masjid. Upaya nâdhir dalam mengelola aset wakaf di Masjid Besar Imam Ulomo Sampung adalah dengan mengembangkan tatakelola wakaf mulai dari penghimpunan aset, 
pengelolaan aset produktif, sampai distribusi hasil wakaf. Khusus pengelolaan aset wakaf produktif dengan model pertanian dan perikanan. Model kemandirian masjid berbasis wakaf di Masjid Besar Imam Ulomo Sampung dengan lebih menekannkan kemandirian aset dalam bentuk wakaf produktif dan kemandirian kelembagaan yaitu pengautan kapasitas nâdhir wakaf. Adapun model kemandirian sisi manfaat masih dalam konteks charity dalam bentuk pemberian santunan kepada masyarakat dlu 'afa'.

\section{Daftar Pustaka}

Anshori, Abdul Ghofur, Hukum dan Praktek Perwakafan di Indonesia, Yogyakarta: Pilar Media, 2005.

Budiman, Achmad Arief, " Partisipasi Stakeholder dalam Perwakafan (Studi Kasus di Rumah Sakit Roemani, Yayasan Badan Wakaf Sultan Agung, dan masjid Agung Semarang)", Al-Ahkam, Vol. 26, No. 1, April 2016.

Direktorat Bimas Islam, Kementerian Agama, 2015.

Nasution, Harun, Islam Rasional Gagasan dan Pemikiran Cet. IV, Bandung: Mizan, 1996.

Ibrahim Mahmud Abd. Al-Baqi., Daur al Waqfi fi Tanmiyat al Mujtama' al Madani (Namudaj al Amanah al 'Ammah li al Auqaf bi Daulah al Kuwait), Daulah Kuwait: Al Amanah al 'Ammah li al Auqaf Idarah ad-Dirasah wa al 'Alaqat al Kharijiyyah, 2006.

Direktorat Pengembangan Zakat dan Wakaf. Paradigma Baru Wakaf di Indonesia. Jakarta: Direktorat Jendreral Bimbingan Masyarakat Islam dan Penyelenggaraan Haji Kemenag, 2015.

Furqon, Ahmad, "Pengelolaan Wakaf Tanah Produktif (Studi Kasus Nazhir Badan Kesejahteraan masjid (BKM) Kota Semarang dan Yayasan Muslimin Kota Pekalongan)", Al-Ahkam, Vol. 26, No. 1, 2016.

Munawir, M. Fajrul, "Fungsi Majid Antara Realita dan Idealita" dalam Fakultas dakwah UIN Yogyakarta, Model-model Kesejahteraan Sosial Islam, Yogyakarta, PMI-Dakwah UIN Sunan Kalijaga-IISEP CIDA, 2007.

Huda, Miftahul, Mengalirkan Manfaat Wakaf Jakarta: Gramata Publishing, 2015. 
"Wakaf dan Kemandirian Pesantren dari Gontor Hingga Tebuireng", ISLAMICA, Vol. 07, No. 01, Sptember 2012.

Huda, Miftahul \& Lukman Santoso, "masjid Wakaf dan Transformasi Sosial Umat", Tapis, Vol. 01, No. 01, July 2017.

Kabisi, Muhammad Abid Abdullah al-, Hukum Wakaf, Jakarta: IIMaN Press, 2004.

Nadjib, Tuti A., \& Ridwal Al-Makassary., Wakaf, Tuhan, dan Agenda Kemanusiaan, Jakarta: CSRS UIN Jakarta, 2006.

Nasution, Harun, Islam Rasional Gagasan dan Pemikiran Cet. IV, Bandung: Mizan, 1996.

Nasution, Mustafa Edwin, \& Uswatun Hasanah, Wakaf Tunai Inovasi Finansial Islam: Peluang dan Tantangan Dalam Mewujudkan Kesejahteraan Umat, Jakarta: Pusat Kajian Timur Tengah dan Islam Universitas Indonesia bekerja sama dengan Bank Indonesia, Serta Departemen Agama RI, 2006.

Tim Penulis, Album masjid Besar Imam Ulomo Sampung, Sampung: Takmir masjid, 2011.

Usman, Nurodin, "Pengelolaan Wakaf Produktif untuk Kesehatan (Studi Kasus Bandha Wakaf masjid Agung Semarang", Muaddib, Vol. 04, No. 02, Juli Desember 2014.

Yani, Ahmad \& Achmad Satori Ismail, Menuju masjid Ideal, Jakarta: LP2SI Al Haramain, 2001.

Nur Hasyim, Hasil Wawancara, 2 Oktober 2017.

Joko Waluyo, Hasil Wawancara, 22 Agustus 2017.

Abdul Aziz, Hasil Wawancara, 14 Agustus 2017. 